\title{
FUZZY MEANS AND HGA-TYPE INEQUALITIES
}

\section{JOANNA NIKODEM AND KAZIMIERZ NIKODEM}

Abstract. The notion of fuzzy means of fuzzy numbers is introduced. Fuzzy counterparts of the arithmetic, geometric and harmonic means are investigated and inequalities between them are presented.

Mathematics subject classification (2020): Primary 26E60; Secondary 26E50, 04A72, 39B62.

Keywords and phrases: Means, fuzzy numbers, fuzzy means, inequalities between fuzzy means.

\section{REFERENCES}

[1] O. A. AbuAarqob, N. T. Shawagfeh, O. A. AbuGhneim, Functions defined on fuzzy real numbers according to Zadeh's extension, Internat. Math. Forum 3 (2008) 763-776.

[2] J. AczéL, J. Dhombres, Functional Equations in Several Variables with Applications to Mathematics, Information Theory and to the Natural and Social Sciences, Cambridge University Press, Cambridge, 1989.

[3] P. S. BULLEN, Handbook of means and their inequalities, Kluwer, Dordrecht, 2003.

[4] G. Chen, T. T. Pham, Introduction to Fuzzy Sets, Fuzzy Logic and Fuzzy Control Systems, CRC Press LLC, Boca Raton, London, New York, 2001.

[5] Z. DARocZY, Z. PÁLES, Gauss-composition of means and the solution of the Matkowski-Sutô problem, Publ. Math. Debrecen 61 (1-2) (2002) 157-218.

[6] M. DHAR, Arithmetic mean, geometric mean and harmonic mean of fuzzy matrices on the basis of reference function, Ann. Fuzzy Math. Inform. 14 (2017) 207-214.

[7] D. Dubois, H. Prade, Fuzzy Sets and Systems: Theory and Applications, Acad. Press, vol. 144, New York 1980.

[8] D. Dubois, H. PRADE, Inverse operations for fuzzy numbers, IFAC Proceedings Volumes, vol. 16 (issue 13) (1983) 399-404.

[9] D. Dubois, H. Prade, The mean value of fuzzy numbers, Fuzzy sets and Systems 24 (1987) 279 300.

[10] D. Dubois, H. Prade (Eds), Fundamentals of Fuzzy Sets, Kluwer Acad Publ., New York, 2001.

[11] N. ElEzović, Asymptotic inequalities and comparison of classical means, J. Math. Inequal. 9 (1) (2015) 177-196.

[12] L. S. GaO, The fuzzy arithmetic mean, Fuzzy Sets and Systems 107 (1999) 335-348.

[13] J. JARCZYK, W. JARCZYK, Invariance of means, Aequat. Math. 92 (2018) 801-872.

[14] A. Kaufmann, M. M. Gupta, Introduction to Fuzzy Arithmetic: Theory and Applications, Van Nostrand Reinhold, New York, 1991.

[15] H. T. NguYen, A note on extension principle for fuzzy sets, J. Math. Anal. Appl, 64 (1978) 369-380.

[16] K. Nikodem, Set-valued means, Set-Valued Var. Anal. 28 (2020) 559-568.

[17] G. Toader, I. Costin, Means in mathematical analysis. Bivariate means, Mathematical Analysis and its Applications Series, Academic Press, An imprint of Elsevier, London, 2018.

[18] L. A. ZADEH, Fuzzy sets, Information and Control 8 (1965) 338-353.

[19] L. A. ZADEH, The concept of linguistic variable and its applications to approximate reasoning, Information Sciences 8 (1975) 199-249.

[20] H. J. Zimmermann, Fuzzy Set Theory and its Applications, Kluwer Acad. Press, 1991. 